\title{
SAMEHANG VAN VERHOUDINGSWOORDE AS MIDDELPUNT VAN VERHOUDINGSHERSTEL IN DIE BOEK HOSEA - 'N SOSIORETORIESE STUDIE
}

\author{
Authors: \\ Johannes C.F. Harris ${ }^{1}$ \\ Pieter M. Venter ${ }^{1}$

\begin{abstract}
Affiliations:
${ }^{1}$ Departement $\mathrm{Ou}$

Testamentiese Wetenskap,

Universiteit van Pretoria,

Suid-Afrika
\end{abstract}

\section{Correspondence to:}

Johannes C.F. Harris

e-mail:

chris@ngpottiessuid.org.za

\section{Keywords:}

Hosea; verhoudingsherstel patrone en beelde; woorde onderlinge

\section{Postal address:}

Privaat Sak X2449,

Mokopane, 0600,

Suid-Afrika

\section{Dates:}

Received: 14 Apr. 2008 Accepted: 10 Feb. 2009

Published: 10 July 2009

How to cite this article: Harris, J.C.F. \& Venter, P.M., 2009, 'Samehang van verhoudingswoorde as middelpunt van verhoudingsherstel in die boek Hosea -'n sosioretoriese studie', HTS Teologiese Studies/Theological Studies 65(1), Art. \#128, 7 pages. DOI: $10.4102 /$ hts. v65i1.128

\section{This article is available} at:

http://www.hts.org.za
(C) 2009. The Authors. Licensee: OpenJournals Publishing. This work is licensed under the Creative Commons Attribution License.

\section{ABSTRACT}

Contiguity of relationship words as focal point for the restoration of relations in the book of Hosea - a socio-rhetorical study

This article reflects on the various nuances in meaning of the relationship terminology used in Hosea. These words are used in combination with one another, although used differently in different contexts. The different combinations create associations with new socioliterary meanings. This culminates in three central, interrelated notions, namely אח ('love as life orientation'), ידעי ('acknowledgement of the care of Yahweh') and 'היד לפני ('to live before Yahweh'). The collective intention of these words is finally described as one of covenant harmony.

\section{INLEIDING}

Die boek Hosea is vol simboliek. Die bekendste hiervan is waarskynlik die beeld van die versteurde verhouding tussen Israel/Juda en Jahwe, soos gesimboliseer deur die huweliksverhouding tussen die profeet Hosea en sy 'owerspelige ${ }^{1}$ vrou. Verhoudingsterme sal derhalwe 'n belangrike sleutel tot die begrip van die boek wees. 'n Belangrike voorbeeld hiervan is Hosea 2:21,22 (Masoretiese teks) in die groter geheel van 2:4-25 [2:1-22] $]^{2}$, wat 'n opeenstapeling van terme bevat wat die redaktor met ' $n$ bepaalde doel so saam gebruik. ${ }^{3}$ Dit kan ook op 'n samehangende verwantskap tussen terme dui (kyk Louw 1982:64). Sekere terme is as 'interpersonal events of association constituting a set of meanings, that is, a semantic field, which may be defined as "to establish or confirm a relationship" " aan mekaar verwant (Louw 1982:64).

Die eindredaktor van die boek Hosea ontleen bepaalde begrippe/terme aan sy leefwêreld, onder

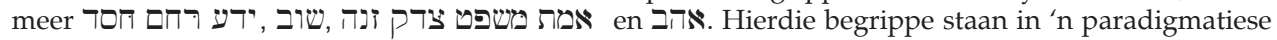
verhouding tot mekaar en is elkeen swaar met sosioliterêre betekenis(se) belaai. Deur hierdie begrippe in ' $n$ beplande geheel byeen te bring, laat die outeur(s) ook hierdie betekenisse met mekaar in wisselwerking tree, en loop dit uit op sentrale begrippe wat die boodskap van die boek omvattend raak (kyk ook Figuur 1). Hierdie sentrale begrippe is בה ('liefde as lewensoriëntasie'), (דיע ('erkenning van Jahwe se sorg') en הכיד לכנ ('lewe voor die aangesig van Jahwe'). Deur die sosioretoriese ontleding van vyf verteenwoordigende tekseenhede uit die boek Hosea, naamlik Hosea 2:4-25 [2:1-22] ; $3: 1-5 ; 4: 1-5: 7 ; 6: 1-6$ en 11:1-11, word ' $n$ eie teorie oor die betekenis van hierdie begrippe in die boek ontwikkel. 'Sosioretoriese ontleding' verwys na 'n kombinasie van sosiologiese en retoriese ontleding: Sosioretoriese kritiek is ' $n$ benadering wat op waardes, oortuigings en geloof konsentreer, sowel in die teks wat ons lees as in die wêreld waarin ons leef (kyk Robbins 1996:1). Die benadering fokus uitvoerig op die teks self, maar beweeg ook na die wêreld van die skrywer(s) van die teks én dié waarin ons tans leef. 'n Teks is soos 'n dik geweefde tapisserie. Elke teks bevat ingewikkelde patrone en beelde. Indien daar eensydig na die teks gekyk word, sien 'n mens 'n baie beperkte weergawe van sy 'tekstuur'. Indien die eksegeet egter telkens uit 'n ander hoek na die teks kyk, sal hy meervoudige teksture kan sien. Elke teks staan in 'n intertekstuele verband met ander tekste. ' $\mathrm{n}$ Teks is dus die ontmoetingsplek van verskillende tekste. Dit is 'n spinneweb (kyk Venter 1997:328-329).

' $\mathrm{n}$ Teks is ook meer as die som van sy woorde. Tekste word, wat onder meer verhoudings van opposisie, ooreenkoms, gedeeltelike ooreenkoms en herformulering betref, deur vorige tekste beïnvloed (kyk Baxandall 1991:6). Hierdie studie toon ook dat tekste en woorde onderling met ander tekste en woorde verbind is en dat dié onderlinge verwantskappe bepaalde betekenisnuanses na vore bring. Uiteindelik word 'n hele netwerk verbintenisse tussen woorde blootgelê (kyk Figuur 1).

\section{DRIE SENTRALE BEGRIPPE}

Die drie sentrale begrippe (kyk Figuur 1) spruit uit die vyf verteenwoordigende tekseenhede (soos vervolgens bespreek) waarin die nege verhoudingswoorde wat vir hierdie ondersoek gekies is, voorkom.
1.Hosea 2:1 beskryf haar as תב זנונים (kyk Snyman 1993:90-111)

2.Die Afrikaanse vertaling se numering word in blokhakies geplaas, terwyl die Biblia Hebraica Stuttgartensia- (Hebreeuse Ou-Testamentiese) indeling sonder hakies verskyn.

3.Childs (1979:381) noem Hosea 1-3 'the exegetical key in the framework from which the entire book is to be read'. Morris (1996:111) voer voorts aan dat 'the most significant way that these chapters serve as an introduction is to present the key words that will be repeated and reinterpreted in what follows'. Hy noem hierdie sleutelwoorde Leitwörter (kyk Morris 1996:111).

4.Die Afrikaanse vertaling se numering word in blokhakies geplaas, terwyl die Biblia Hebraica Stuttgartensia- (Hebreeuse Ou-Testamentiese) indeling sonder hakies verskyn. 

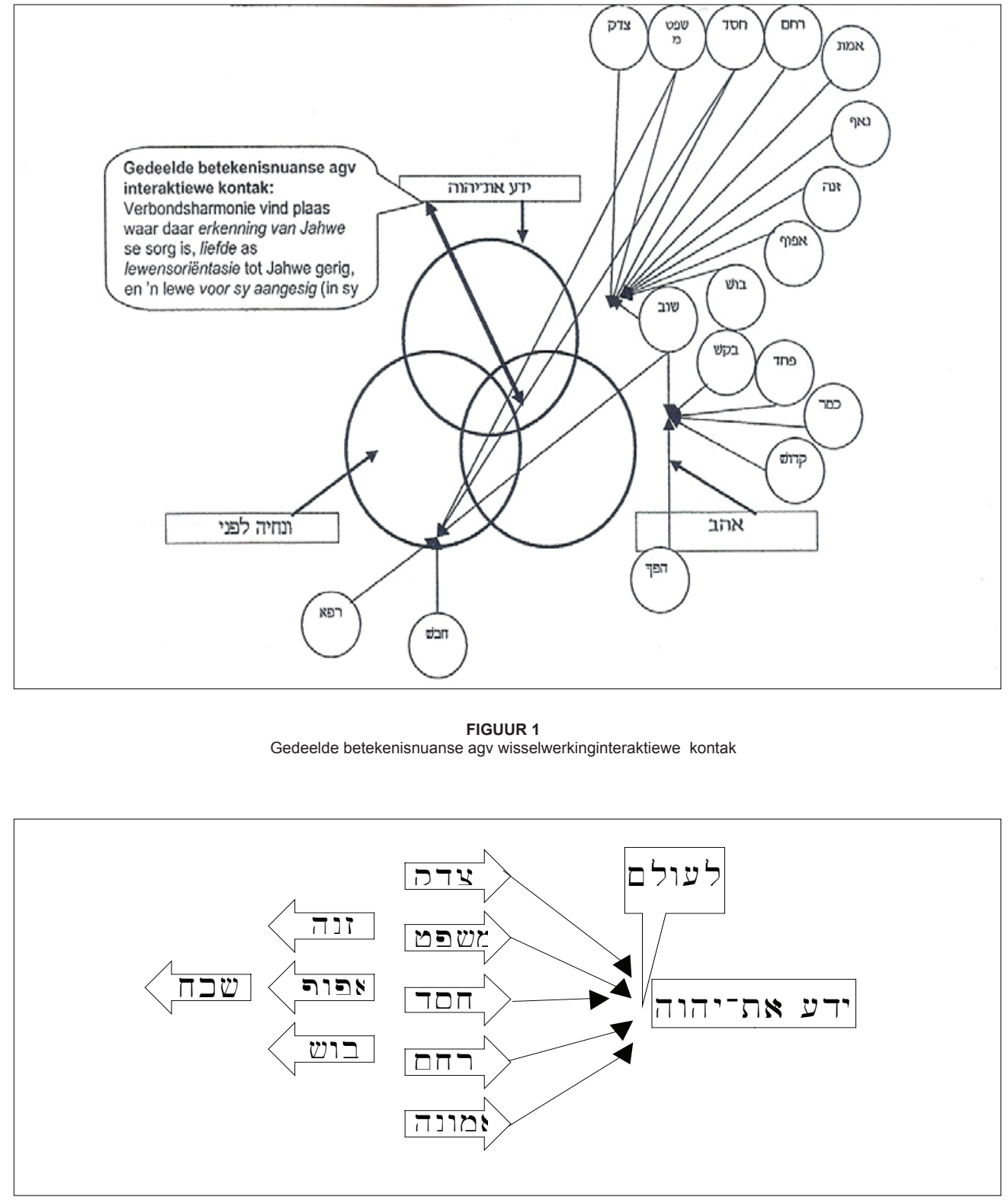

FIGUUR 2

'Huweliksverbintenis' beskrywe deur sinonieme parallellismes

\section{עד' ('erkenning van Jahwe se sorg')}

\section{Hosea 2:4-25 [2:1-22]}

Die tematiese eenheid van Hosea $2: 4-25$ is 'n poëties gestruktureerde geheel waarin 'n hele aantal parallelismes tot betekenisverryking lei. Strukturele ontleding toon dat dié gedeelte volmaak soos 'n skarnier toevou, met vers 15 as middelpunt (kyk Lys 1976:66). Die hoogtepunt van die klag teen Israel is dat sy die Baäls as haar minnaars/dié wat sy liefhet, vereer, en Jahwe misken. Die struktuur bring ook die volgende aan die lig:

- Naaktheid beteken die einde van religie (verse 12-13);

- hofmaak (liefde) lei tot die teruggee van natuurgawes (verse 16(b) en 17(a));

- die woestyntyd word as 'n 'nuwe eksodus' voorgehou verse16(a) en $17(b)$

- dié nuwe eksodus word as 'n tyd van hofmaking en liefde en die teruggee van natuurgawes (verse 11-14 en 16-17), maar

5.Die Afrikaanse vertaling se numering word in blokhakies geplaas, terwyl die Biblia Hebraica Stuttgartensia- (Hebreeuse Ou-Testamentiese) indeling sonder hakies verskyn. ook as 'n tyd van erkenning van Jahwe as die God wat seën, uitgebeeld

- זמנונה ('promiskuïteit') ('verbondsgetrouheid') in verse 21-22;

- die verbreekte verhouding (vers 4) staan teenoor die herstelde verhouding (vers 25);

- hoerery/promiskuiteit staan gelyk aan owerspel in die konteks van 'n huweliksverhouding.

• שכדי אתי-יהוד ('erkenning van Jahwe').

In verse 21 en 22 volg drie sinonieme parallelismes om die aard van die 'huweliksverbintenis' tussen Jahwe en Israel te beskryf. Die verbintenis sal לעולם ('vir altyd') wees. Jahwe sal Hom verloof in צדק ('bedagsaamheid'), משפט ('regverdigheid'), חם ('verbondsliefde'),םחר('barmhartigheid') en אמורניא('verbondstrou'). Dít staan teenoor die ontrouheid van Israel (verse 6-7). Hierdie word grafies voorgestel in Figuur 2.

6.Ten einde ' $n$ élite groep voor te stel wat deur vreemdelinge binnegedring is, beskryf Hosea 'n promiskue vrou wat toelaat dat haar liggaam deur haar minnaars gepenetreer word (kyk Yee 2001:31) 


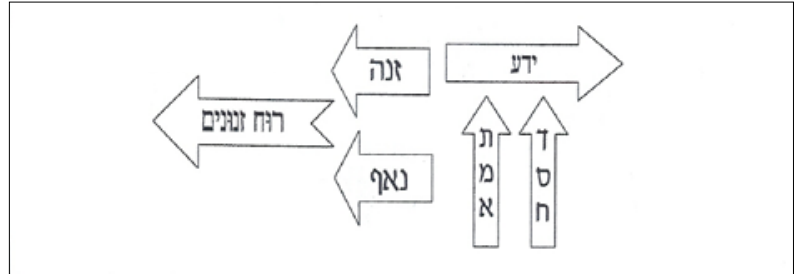

FIGUUR 3

Verbondsontrouheid by die volk

Die resultaat van die nuwe verbintenis (die huwelik) is dat Israel Jahwe sal erken (ידעי אתייהודי) as die Een wat werklik sorg (kyk Figuur 2). Wat die huweliksterminologie betref, is עדי ('erkenning van Jahwe') derhalwe die hoogtepunt van die huweliksvoltrekking. Hosea gebruik die huweliksmetafoor teologies om sy polemic monolatry ${ }^{7}$ (kyk Yee 2001:8; Dearman 1992:36; Smith 1990:42-45) te verkondig. Sy aanklagte is hoofsaaklik op 'n manlike gehoor, onder meer die koning en sy politieke en kultiese élite, gerig. Die huweliksmetafoor vervroulik die manlike heersende hiërargie deur hulle gesamentlik as 'n promiskieuse vrou uit te beeld. Hosea se huwelik met 'n אשת זערונים (promiskieuse vrou) moet as 'n 'simboliese optrede' verstaan word (kyk ook Yee 2001:30-32). Die simboliek het saam met die profetiese boodskap gegroei, en sou nie by die huweliksvoltrekking reeds só verstaanbaar gewees het nie. Die simboliek dui daarop dat Israel Jahwe nie eksklusief vereer het nie. Die ontrouheid verwys na die volk se godsdienstige ontrouheid teenoor Jahwe. Volgens die status-/ בkandekultuur (kyk Malina 1993:73-77) het Israel nie net ('skandelik opgetree') nie (vers 7), maar word sy ook in die

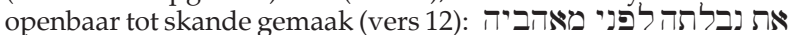
אגל ה'Ek sal dan nou haar skaamte ontbloot voor die oë van haar minnaars ...' $)^{8}$. Israel word derhalwe daarmee uitgedaag om iets te doen om hulle eer te herstel (challenge response). Dít geskied binne die raamwerk van die verlies van status en manlike eer (kyk Yee 2001:30-32), en die geskenke (verse 21-22) is dan ook die verlangde regstelling van hulle ontrouheid.

Wat kulturele kategorieë betref, is die perikoop deel van ' $n$ regsgeding waarin 'opposisie- kulturele retoriek' gebruik word. Daar word sterk teen die ontaarde kultus standpunt ingeneem. Die godsdiensbeoefening wat gekritiseer word (deur van kras woorde en begrippe soos אפרך ('owerspel') en ונפה ('promiskuïteit') gebruik te maak), word gekorrigeer deur in verse 4 en 18 terme soos ('man') en אש ('vrou') uit die betekenisveld van die huwelik; 'voorsiening van lewensmiddele' (vers 10); asook 'huweliksgeskenke', naamlik צדק ('bedagsaamheid'), משכט ('regverdigheid'), חסד ('genade'), רחם ('barmhartigheid') en אמר הפת ('verbondsgetrouheid'), te gebruik. Die verlangde reaksie, "דיע אתדיהודי ('dat Israel aan Jahwe erkenning gee'), maak die huweliksverhouding volkome (herstel). In bostaande verwantskap, kry die verhoudingsterme dus die volgende nuanses:

- רח: ontferm; barmhartig wees (v 6, 21)

- זנז: promiskuïteit (v 4, 6, 7)

- צדי: bedagsaamheid (v 21)

- משפטי: regverdigheid (v 21)

-

- אמפת: verbondsgetrouheid (v 21)

- בט: terugkeer (v 9, 11)

- שכד: misken (vergeet) (v 15)

- $\quad$ שדי?: erkenning (v 10, 22)

\section{Hosea 4:1-5:7}

Hierdie eenheid bestaan uit drie poëtiese eenhede, naamlik Hosea 4:1-3; 4:4-19 en 5:1-7.9 Die verhoudingsterme ידעי en

7.Die aanbidding van een God, met erkenning dat daar ander gode is, dog krities en onverdraagsaam teenoor hulle.

8.Aanhaling uit die 1953 - Afrikaanse vertaling

9.Die indeling word op dié van Wolff $(1965: 81,87,119)$, Andersen \& Freedman
זנו, wat onderskeidelik vyf keer (Hos 4:1, 6; 5:3,4) en tien keer (Hos 4:10, 11, 12, 13, 14, 15, 18; 5:3, 4) voorkom, is ondersoek.

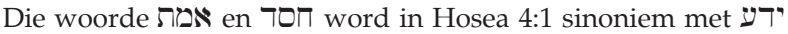
gebruik, en is derhalwe deel van die ondersoek. Die volgende betekenisnuanses kom voor:

- זנה verwys na Israel se verbondsontrouheid. Dit dien as simbool van die ontbindende verhouding tussen Israel en Jahwe. Dié agteruitgang is aan die רוח זונים ('gees van promiskuïteit') te wyte (kyk Hos $4: 12 ; 5: 4) .{ }^{10}$

- Hierdie hoergees is ' $n$ gesindheid wat die denke van Jahwe aflei. Dit gaan volgens Hosea 4:11,18 met brassery gepaard

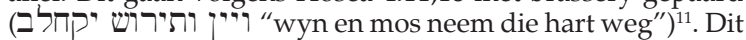
maak hulle פטממא ('onrein') (Hos 5:3), wat beteken dat hulle nie vir Jahwe aanvaarbaar is nie.

- Hierdie gees maak hulle ook ('versot op erotiese passie') (Hos 4:18). Dit dien dan ook as sinspeling op die misplaaste אה ('oriëntasie') wat hulle na regte aan Jahwe verskuldig is. Die verbondsontrouheid kom verder in die kultus tot uiting. Die volk se offerpraktyke aan die Baäls (Hos 4:12,13) geskied onder leiding van die priesters (Hos 4:6,14). Dit lei volgens Hosea 4:13 regstreeks tot ('hoerery/prostitusie') en באי ('owerspel') (sinonieme parallelisme in Hos 4:13). ${ }^{12}$ Albei terme verwoord die volk se verbondsontrouheid. Die leiers se verantwoordelikheid ten opsigte van die volk se verbondsgetrouheid word dus hierdeur beklemtoon.

- Die priesters se gebrek aan "דעי ('erkenning') van Jahwe (Hos 4:6) lei tot ongehoorsaamheid en grootskaalse ontrouheid. Gebrek aan 'ידע' ('erkenning') van Jahwe ontstaan by die kultus, waar Jahwe vir die Baäls verruil is. ז is dus die teenpool van $\boldsymbol{V I}^{\boldsymbol{M}}$, en dra daarom hier die betekenis van 'miskenning' van Jahwe (kyk Figuur 3).

- Die chiasme in Hosea 4:6 nuanseer die betekenis van

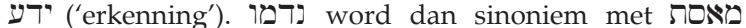
gebruik. 'Die volk gaan ten gronde' word aan 'verwerping deur Jahwe' gelykgestel. מבל י הדעת staan parallel met

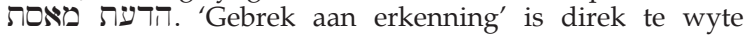
daaraan dat die volk 'kennis verwerp het' (en nie toegewyd was aan Jahwe nie). ${ }^{13}$

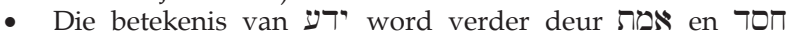
bepaal (Hos 4:1), wat onderskeidelik die betekenis van 'verbondsliefde' en 'betroubaarheid' dra.

As metafore vir die huweliks- (verbonds-)verhouding tussen Jahwe en Israel, dui dit daarop dat ' $n$ gesindheid van ontrouheid en dislojaliteit tot die miskenning van Jahwe as 'die Een wat sorg' aanleiding gee.

\section{יה ('lewe voor sy aangesig')}

\section{Hosea 6:1-6}

Die volgende verhoudingsterme is ondersoek: שוב ('terugkeer') in Hosea 6:1; 'דע ('erkenning') in Hosea 6:3,6; en שסוב ('liefde') in Hosea 6:4,6. Die volgende betekenisnuanses kom voor:

- Die priesterlike boetelied in Hosea 6:1-3 plaas deur middel van die kohortatiewe in verse 1 en 3 שוב ('terugkeer') en ידע ('erkenning') naas mekaar. Om dus na Jahwe terug te keer, behels om aan Hom erkenning te gee.

- שוב Die oogmerk van ('terugkeer') is ('sodat ons voor sy aangesig kan lewe') in vers $2 b$ (kyk Figuur 4 ). Dit is dus ' $n$ begeerte om in die teenwoordigheid van Jahwe te lewe.

- שוב is 'n deurdagte besluit en n' doelbewuste handeling.

- Die gebruik van die sinonieme parallelisme in Hosea 6:6 מסד ('verbondsliefde') en ('דע אלהים ('erkenning van God') op dieselfde betekenisvlak. Dít beteken dus dat Israel se prioriteitskeuse hulle vlak van erkenning jeens Jahwe

(voetnota 9 gaan voort...)

(1980:317, 331, 342-344, 380), Jeremias (1983:59, 63, 73), Vosloo (1992:248) en Boshoff (1994:88) gegrond.

10.Kyk vorige hofie, Hosea 2:4-25 [2:1-22], waar זנה met promiskuïteit vertaal is 11.Aanhaling uit die 1953-Afrikaanse vertaling.

12.Kyk Figuur 3

13.Kyk hofie Hosea 2:4-25 [2:1-22] 


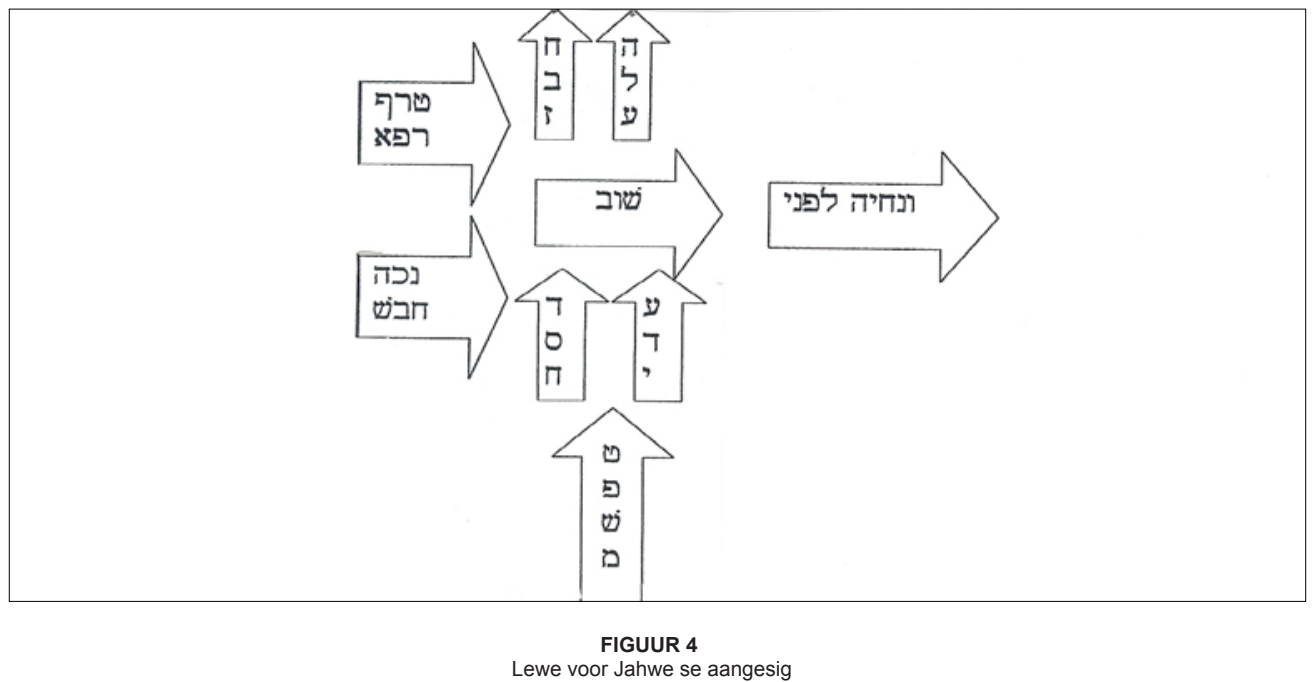

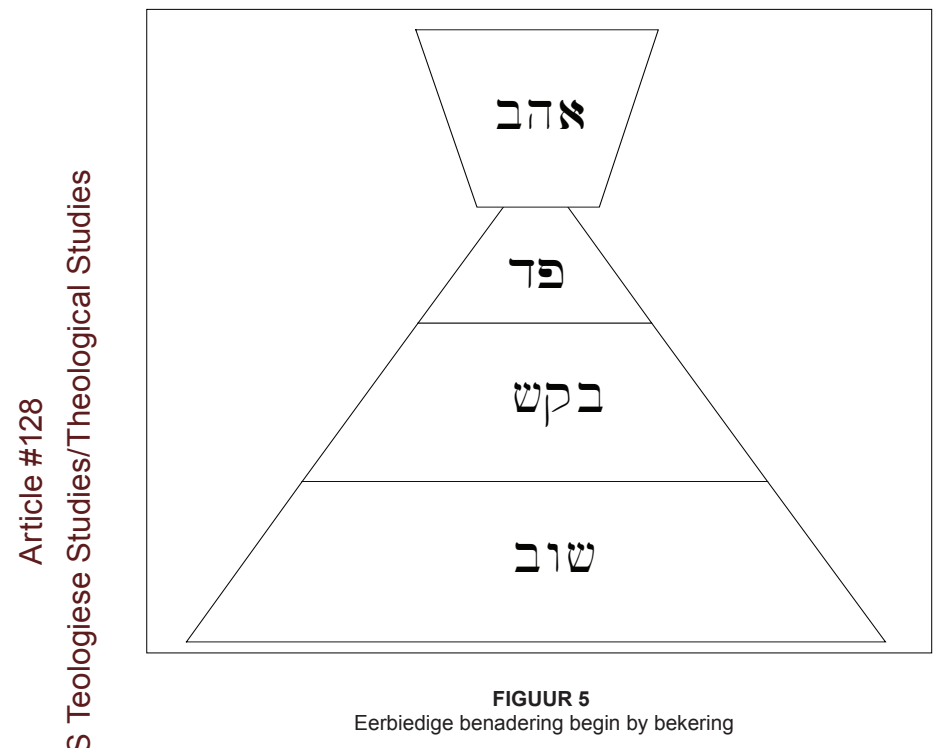

bepaal, of anders gestel, dat hulle gebrek aan erkenning jeens Jahwe daaraan te wyte is dat hulle nie aan Hóm lojaal is nie, maar aan die Baäls.

- Die gewenste resultaat van Jahwe se 'oordeel' (verse 4-5)

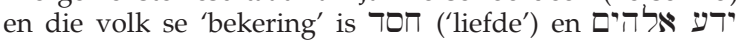
('erkenning/toewyding aan God').

- In 'n status-/skandekultuur is die oogmerk van die priesterlike boetelied in Hosea 6:1-3 om Jahwe uit te daag (challenge response) om hulle (die volk) te $\aleph$ אפר ('genees') en te חבש ('verbind'). In reaksie daarop is Jahwe se oordeel in Hosea 6:5'n uitdaging tot bekering tot Tסד ('verbondsliefde') en ידע אלהים' ('erkenning van God').

- Aangevuur deur die משפט ('oordeel') van Jahwe, word die ontaarde kultus in Hosea 6:6 in terme van ('offerandes') en עםד ('brandoffers') teen die suiwere ('liefde') en ידע אלהים ('toewyding aan/erkenning van ons God') uitgespeel.

- Die beginsel van wederkerigheid in die begunstiger/ begunstigde-(patron/client-)verhouding tussen Jahwe en Israel kom in die konsep van שוב ('terugkeer') binne die verbondsverhouding na vore. In hierdie verhouding verteenwoordig die terme חסע אלהים ('liefde') en ('erkenning van God') Israel se verlangde reaksie, en word dit dan ook sinoniem gebruik.

- Die uiteindelike resultaat is (sodat ons voor sy aangesig kan lewe').

Die onderlinge verwantskappe word in Figuur 4 uitgebeeld.

\section{בהא('liefde as lewensoriëntasie')}

\section{Hosea 3:1-5}

Die volgende verhoudingsterme is ondersoek: Die sleutelwoord in die perikoop is ('lewensoriëntasie'), wat vier keer in vers 1 herhaal word. Die tekens van Jahwe se אה אוב kom in verse 2 en 5 na vore. Verder is שוב ('bekeer') ondersoek, soos wat die betekenis daarvan in vers 5 saam met ('soek') en פחד ('met eerbied benader') ontvou. Die volgende betekenisnuanses blyk hieruit:

- Jahwe se liefde word in vers 1 struktureel met die liefde van die vrou se beminde vergelyk. Die owerspel wat sy bedryf, word met die 'wend tot ander gode' vergelyk. Sinoniem met die 'wend tot ander gode' is die ואהבי אשישי ענבים ('versot wees op rosynekoeke'). Dít dui op die aard van die volk se owerspel, naamlik dat hulle die vrugbaarheid van die land gevier het deur rosynekoeke aan die Baäls te offer. אה מה het dus hier die nuanse van 'lewensoriëntasie'.

- Die chiasme in vers 3 impliseer dat die 'stilsit vir 'n lang tyd 'wedersyds sal gebeur (by sowel Jahwe as Israel). 'Om nie te hoereer nie', soos vervat in die chiasme, beteken om 'aan geen man te behoort nie'. As Jahwe se stilsit dus deur sy aangevuur is, behoort die uiteinde van Israel se stilsit ook אהב ('lewensoriëntasie') tot Jahwe te wees (kyk ook eerste punt onder die hofie Hosea 6:1-6).

- Die voortskrydende parallelismes in vers 5 dui op ' $n$ Steigerung van 'bekeer', 'na Jahwe soek', en 'Jahwe met siddering benader'. Bekering bereik dus 'n hoogtepunt wanneer Jahwe uiteindelik met eerbied benader word (kyk Figuur 5):

Bekering is volgens hierdie parallelisme die beginpunt van die terugkeer na Jahwe. Dit is dus in wese niks anders nie as wat op 'lewensoriëntasie' dui.

- Die אהב ('wederliefde/wedersydse oriëntasie') in die verband van die verhouding tussen Jahwe en sy volk het nie net raakvlakke met die soort verhouding tussen 'n man en 'n vrou nie, maar word wat inhoud betref daardeur bepaal.

- Sosiologies het Israel skandalig opgetree (vers 1) deur ומנצפתת ('sy het gehoereer'). Derhalwe word sy van haar godsdienstige vastigheid gestroop (verse 3 en 4) en daarmee uitgedaag om iets te doen om haar eer te herstel (challenge response). Die verlangde reaksie word in vers 5 as שוב ('bekering/terugkeer/om jou oriëntasie te verander') aangedui.

- Deur die verwysing na die gebroke 'huweliksverhouding' (vers 1 ) en die moratorium op dié verhouding (vers 3 ), is daar sprake van die beginsel van wederkerigheid in die begunstiger/begunstigde-verhouding tussen Jahwe en Israel. 


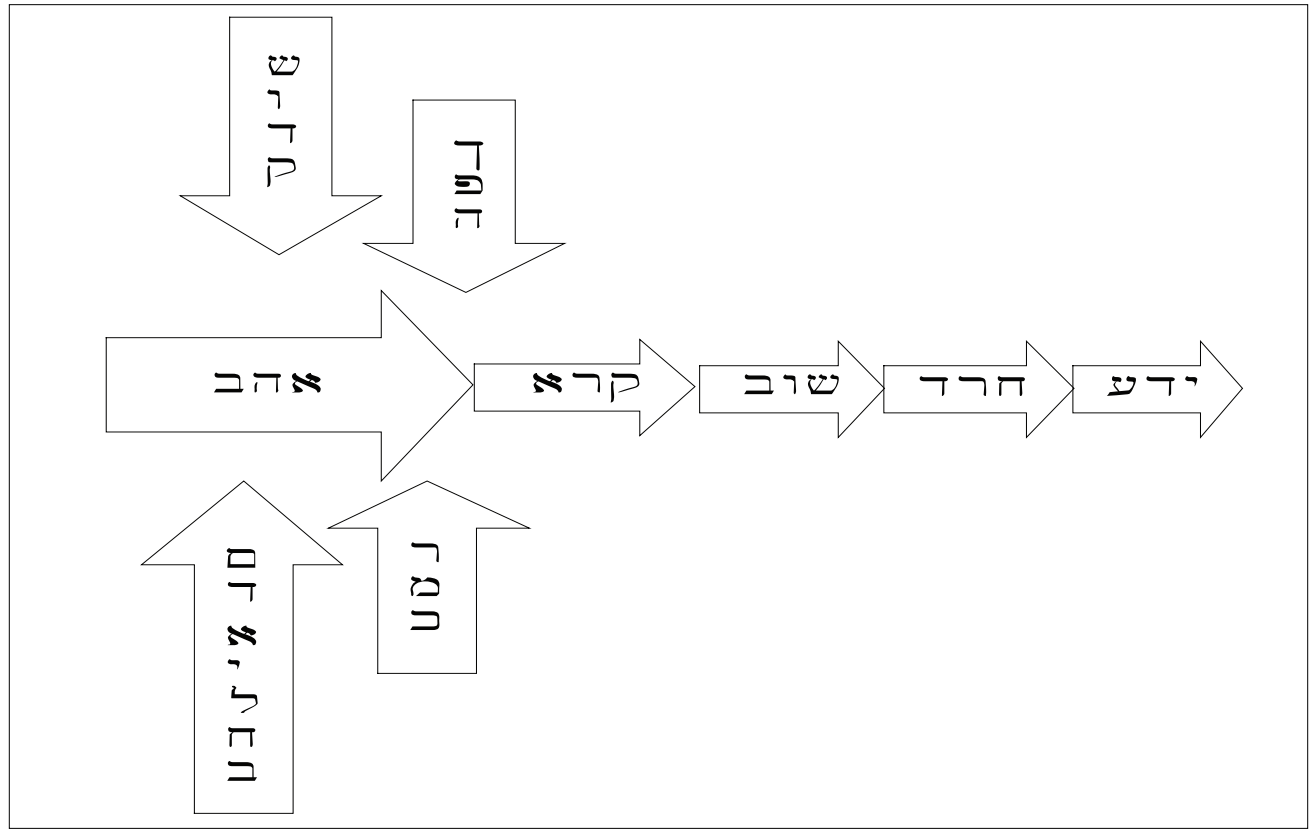

FIGUUR 6

Jahwe daag Israel uit om sy liefdesdade te beantwoord

- Volgens die reinigingskodes moes Israel weer 'n woestyntyd (reinigingstyd) beleef. Dit word hier as 'n verootmoedigingstyd aangedui waarin afsondering en toewyding ' $\mathrm{n}$ belangrike rol speel. Die volk se verval word in Hosea 3 deur die kras woord ('maar sy het gehoereer/owerspel bedryf') aangedui.

- Die uiteindelike verlangde regstelling word in vers 5 as שוב ('bekeer'), כקש ('soek') en כדר ('met eerbied benader') voorgehou. Dit verwys natuurlik na die kinders van Israel se verlangde sosiale reaksie op die profeet Hosea se simboliese handeling met Gomer, sy vrou.

- Uiteindelik het die terme onder beskouing, naamlik ('wederliefde / wedersydse oriëntasie') en שוב ('bekering/ terugkeer/om jou oriëntasie te verander'), soos uit hulle verwante gebruike in Hosea 3:1-5 blyk, albei die nuanse van ' $n$ verlangde oriëntasie ten aansien van Jahwe. Ander verwante terme wat die woorde se betekenis beïnvloed, soos בקט ('soek') en ('meteerbied benader'), is ook ondersoek. Dieverwantskap tussen hierdie verhoudingsterme beïnvloed dus hulle betekenisnuanse, en bevestig so die hipotese van hierdie studie.

\section{Hosea 11:1-11}

Die volgende verhoudingsterme is ondersoek, אד ('liefde') in vers 1 en 4 ; שוב ('bekeer/terugkeer') in vers 5; en חרדד ('hulle sal sidderend aankom') in vers 10 en 11. Hieruit kom onderstaande betekenisnuanses na vore:

- Die histories-teologiese beskuldiging in Hosea 11:1-11 plaas ('liefde') en ('roep') in vers 1 deur 'n sinonieme parallelisme naas mekaar, sodat אח van 'soek' het (kyk hofie Hosea 3:1-5 vroeër in die artikel). ${ }^{14}$ Jahwe se liefde 'soek' na wederliefde. Die verdere die profete in vers 2 en 7 ontstaan uit hierdie liefde van Jahwe wat na beantwoording soek.

- Die chiasme in vers 4a maak dat die בעבתות אהבה ('met koorde van liefde') deur die gepaardgaande sinonieme frase בחל י "אדם ('met mensebande') as 'n mensgerigte handeling gelees moet word. Hoewel Jahwe se liefde dus ('heilig/ goddelik') is, is dit ook menslik (menssoekend en -gerig). ${ }^{15}$

14.Kyk Figuur 6

15.Kyk Figuur 6
- Hoeweldiewoordユーハ('liefde') invers8-9ontbreek, word die innerlike worsteling in die $\beth$ ('hart') van Jahwe semanties betrek, en dien die woorde ('my hart is omgekeer') en במר ('my medelye is opgewek') ter betekenisverryking van בה. Jahwe, die Heilige, se menssoekende liefde is daarom ook medelydend en kwesbaar.

- Die אח ('liefde') van Jahwe roep om ('erkenning').

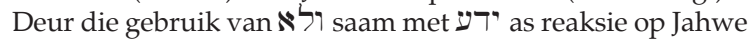
se liefde, kry ידע die betekenis van kennis/aanvaarding/ positiewe erkenning van Jahwe se liefde ${ }^{17}$.

- In vers 5 kry die weiering om te שוב ('bekeer/terug te keer') die betekenisnuanse 'om weg te wees van Jahwe se teenwoordigheid', aangesien Israel se versuim om te bekeer op ballingskap by Assur uitloop. Die woord חרד ('hulle sal sidderend aankom') in vers 10 en 11 word in dieselfde semantiese veld as שוב gebruik (kyk hofie Hosea 3:1-5 vroeër in die artikel). Die chiasme in vers 10 stel sinoniem met.

- אחרי ידוה ילכו ('hulle sal agter Jahwe aan trek'). Die betekenis van שוב שרד is dus by implikasie om agter Jahwe, en nie (meer) agter die Baäls nie, aan te trek.

- Jahwe wys vervolgens sy kwesbare liefdeshart in vers 8-9, waarna die verlangde reaksie op hierdie liefdesuiting in vers 10-11 volg, naamlik חרד ('met siddering naderkom/agter Jahwe aan trek/Hom na te volg') ${ }^{18}$

- In die status-/skandekultuur het Jahwe Israel uitgedaag (challenge response) om sy בה ('liefde') en liefdesdade te beantwoord (verse 1-4, 8-9). Die verlangde reaksie is שוב ('bekering'), חרד ('met siddering aankom/terugkeer') en "די' ('erkenning'). ${ }^{19}$

Die wisselwerking van dié verhoudingswoorde word in Figuur 6 uitgebeeld.

17.Kyk hofie Hosea 2:4-25 [2:1-22] en היה לפני ('lewe voor sy aangesig') vroeër in artikel.

18. Kyk hofie Hosea 3:1-5 vroeër in artikel en Figuur 6 hier bo.

19. Kyk hofie Hosea 2:4-25 [2:1-22] vroeër in artikel. 


\section{DIE BETEKENISNUANSES VAN DIE VERHOUDINGSWOORDE ONDER BESKOUING}

Die verhoudingswoorde onder beskouing, naamlik חסד, אמת , משפט , צדק, זנה , שוב ,ידע, , אהחם, het in hulle wisselwerking (kyk die besprekings onder die 'Drie Sentrale Begrippe' sowel as Figure 1-6) en gekombineerde gebruike verskeie betekenisladings, soos reeds aangedui. Ter opsomming staan die volgende interaktiewe betekenisse uit:

חם: Dit is ' $n$ verbondsbegrip wat in Hosea 2:22 met verwysing na 'n huweliksgeskenk gebruik word, waar dit ook die betekenisnuanse van 'verbondsliefde ${ }^{\prime 20}$ het vanweë die sinonieme parallelisme met רחם ('ontferming/barmhartigheid). ${ }^{21}$ Hierdie woordpaar se betekenis word in Hosea 2:22 ook deur

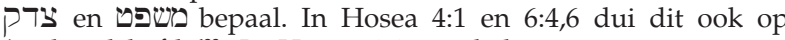
'verbondsliefde' ${ }^{\prime 22}$. In Hosea 6:6 word die term sinoniem met 'דע ('erkenning van God') gebruik. Dáár verleen dit dus aan verbondsliefde die betekenisnuanse van 'toewyding ${ }^{23}$.

רחם: Saam met ('verbondsliefde') in Hosea 2:21, het dié term die betekenis van 'barmhartigheid'. In Hosea 2:6, 25 het dit die algemene betekenis van 'omgee/ontferm'24.

דע": Dié woord word hoofsaaklik vir Israel se verlangde reaksie op Jahwe se liefde gebruik. ${ }^{25}$ In Hosea 2:10, 4:1, 5:4 en 11:3 dui dit op 'erkenning aan Jahwe' vir sy liefde ${ }^{26}$. In Hosea 5:3 beteken dit 'om te ken', en in Hosea 4:6 op 'kennis' (wat die priesters moes oordra). In Hosea 6:3, 6 is die betekenisnuanse 'toewyding aan God' (parallel met חסד, oftewel 'verbondsliefde', in Hosea $6: 6) .{ }^{27}$

צדק: As deel van die מהרק in Hosea 2:21, dra dié woord saam met חסד ('regverdigheid'), en parallel met ('verbondsliefde') en רחם ('barmhartigheid'), die betekenisnuanse van 'bedagsaamheid' (kyk hofie Hosea 2:4-25 [2:1-22] en Figuur 2). ${ }^{28}$ משפט ('bedagsaamheid') in Hosea 2:21, beteken dié woord hier 'regverdigheid' ${ }^{\prime 29}$.

אמת אלית: Dié woord staan parallel met ('lojaliteit') en אסדים ידע ('erkenning van Jahwe') in Hosea 4:1. In dié verwantskap beteken dit 'verbondstrou' 30 .

בא: As imperatief in Hosea 3:1 beteken dié term 'bemin'. Aan die einde van die vers word dit die term wat God se liefde teenoor Israel beskryf. Dit word dus 'n term wat 'lewensoriëntasie' beskryf ${ }^{31}$. In Hosea 11:1 word dit terugskouend met 'liefde' vertaal om al Jahwe se versorgingshandelinge jeens Israel saam te vat ${ }^{32}$. Op dieselfde semantiese gebied word אהב in

20.Kyk Koehler en Baumgartner (1994, Vol 1:336) wat die betekenisnuanses as 'gesamentlike verpligting tussen familie' of 'lojaliteit' of 'getrouheid' aandui.

21.Kyk hofie Hosea 2:4-25 [2:1-22] en Figuur 2 vroeër in artikel.

22.Kyk hofie Hosea 4:1-5:7 en היה לפני ('lewe voor sy aangesig').

23.Kyk hofie 'היה לפני ('lewe voor sy aangesig')

24. Kyk hofie Hosea 2:4-25 [2:1-22]

25. Kyk Koehler en Baumgartner (1994, Vol 2:390-391) wat die betekenisnuanses as 'om te ken; te verstaan' aandui.

26.Kyk hofie Hosea 2:4-25 [2:1-22], Hosea 4:1-5:7, היה לפני ('lewe voor sy aangesig')en Hosea 11:1-11.

27.Kyk hofie היה לפני ('lewe voor sy aangesig') en Figuur 4, albei vroeër in die artikel.

28.Kyk Koehler en Baumgartner (1994, Vol 3:1002-1003).

29. Kyk hofie Hosea 2:4-25 [2:1-22] en Figuur 2.

30.Kyk hofie Hosea 4:1-5:7 en Figuur 3

31.Kyk hofie Hosea 3:1-5 en Figuur 5. (Kyk Koehler en Baumgartner (1994, Vol 1:17-18) wat die betekenisnuanse as 'liefde wat iets doen' aandui)

32.Kyk hofie Hosea 11:1-11 en Figuur 6
Hosea 11:8 ook deur die terme ('omgekeer/kwesbaar') en ד्ञ ('medelydend') verryk ${ }^{33}$. Jahweseliefdeas'lewensoriëntasie' jeens Israel is derhalwe in wese 'kwesbaar' en 'medelydend'.

שוב: As verhoudings-/verbondsterm dui dié woord in Hosea 2:9,11;5:4; 6:1 en 11:5 Israel se 'terugkeer' na Jahwe aan ${ }^{34}$. In Hosea 3:5 maak die term deel uit van ' $n$ voortskrydende parallelisme met בקד ('soek') en פדש ('met siddering benader') ten opsigte van Jahwe ${ }^{35}$. Dit dui die aanvang van die terugkeerproses na Jahwe aan, en beteken dus 'om jou lewensoriëntasie te verander' ${ }^{36}$ As sulks is die resultaat dan 'liefde'. In Hosea 11:9 dui die term Jahwe se terugkoms na Israel aan $^{37}$.

זנ: Dié term dui Israel se verbondsontrouheid aan. As algemene term vir ontrouheid dra dit in Hosea 2:4,6,7; $3: 3$ en $4: 10,12,13,15,18$ die betekenis van 'hoerery/promiskuïteit' ${ }^{38}$. In sy intensiewe vorm in Hosea 4:18, beteken dit 'om versot te wees op erotiese passie ${ }^{39}$. Dáár dui dit die intensiteit van Israel se ontrouheid aan. As huweliksterm word dit in Hosea 4:13 saam met die tegniese term vir owerspel, (נָ), gebruik ${ }^{40}$. In Hosea 4:12 en 5:4 word aangedui dat dít wat Israel tot ontrouheid gedryf het, 'n רוח זונים ('gees van owerspel') was, of dalk dat

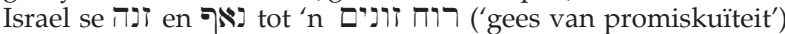
aanleiding gegee het. ${ }^{41}$

\section{OPSOMMING}

Jahwe word dus in die boek Hosea as die Enigste tussen die gode (polemic monolatry) beskryf - die Heilige God wat in sy versorgende liefde sowel medelydend as kwesbaar is. Deur sy ewige verbondstoewyding aan bedagsaamheid en regverdigheid genade en barmhartigheid, daag Hy sy kinders deur beproewings (woestyntyd) uit om hulle van hulle verbondsontrouheid te bekeer, en om aan Hom die eer, erkenning, liefde en toewyding te gee wat Hom toekom. Dán sal daar verbondsharmonie plaasvind, en sal hulle in veiligheid woon.

\section{NOTA}

Hierdie artikel is gegrond op die outeur se navorsing vir ' $n$ DDproefskrif met die titel "n Sosioretoriese ondersoek na bepaalde begrippe in die boek Hosea'. Die proefskrif is voorberei onder promotorskap van prof Pieter Venter, Fakulteit Teologie, Universiteit van Pretoria (2008).

\section{LITERATUURVERWYSINGS}

Andersen, F.I. \& Freedman, D.N., 1980, Hosea: A new translation with introduction and commentary, Doubleday, New York.

Baxandall, M., 1991, 'Figures in the Corpus: Theories of Influence and Intertextuality', in J. Clayton \& E. Rothstein (reds.), Influence and Intertextuality in Literary History, University of Wisconsin Press, Madison.

Boshoff, W.S., 1994, 'Die boek Hosea en die Jahwe-Baäl stryd', DD-proefskrif, Universiteit van Pretoria, Pretoria.

Childs, B.S., 1979, Introduction to the Old Testament as Scripture., Fortress Press, Philadelphia.

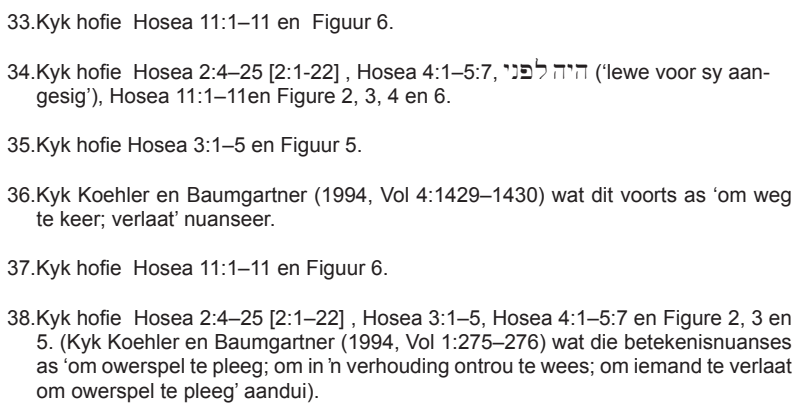

38. Kyk hofie Hosea 2:4-25 [2:1-22] Hosea 3:1-5, Hosea 4:1-5:7 en Figure 2, 3 en 5. (Kyk Koehler en Baumgartner (1994, Vol 1:275-276) wat die betekenisnuanses as 'om owerspel te pleeg; om in ' $n$ verhouding ontrou te wees; om iemand te verlaat om owerspel te pleeg' aandui).

39. Kyk hofie Hosea 4:1-5:7 en Figuur 3

40.Kyk hofie Hosea 4:1-5:7 en Figuur 3

41.Kyk hofie Hosea 4:1-5:7 en Figuur 3, albei vroeër in die artikel. 
Dearman, J.A., 1992, Religion and Culture in Ancient Israel, Hendrickson Publishers, Peabody.

Jeremias, J., 1983, 'Der Prophet Hosea', Das Alte Testament Deutsch 24(1).

Louw, J.P., 1982, Semantics of New Testament Greek, Fortress Press, Philadelphia.

Lys, D., 1976, 'J'ai Deux Amours: Ou l'Amant Jugé', Etudes Theologiques et Religieuses 51.

Malina, B.J., 1993, The New Testament World: Insights from Cultural Anthropology, John Knox Press, Atlanta.

Morris, G., 1996, 'Prophecy, Poetry and Hosea', Journal for the Study of the Old Testament suppl. ser. 19.

Richardson, M.E.J., 1994, The Hebrew and Aramaic Lexicon of the Old Testament (HALOT), L. Köhler \& W. Baumgartner (eds.), vol. 1-4, Koninklijke Brill NV, Leiden.
Robbins, V.K., 1996, Exploring the texture of texts. A guide to socio-rhetorical interpretation, Trinity Press International, Pennsylvania.

Smith, M.S., 1990, The early history of God: Yahweh and the other deities in ancient Israel, Harper and Row, San Francisco.

Snyman, G., 1993, 'Social Reality and Religious Language in Hosea 1-3', Old Testament Essays 8, 90-112.

Venter, P.M., 1997, 'Intertekstualiteit, kontekstualiteit en Daniël 9', In die Skriflig 31(4), 327-346.

Vosloo, W., 1992, 'Die samestelling en struktuur van die boek Hosea', Skrif en Kerk 13, 244-252.

Wolff, H.W., 1965, 'Dodekapropheten 1: Hosea 2', Biblischer Kommentar: Altes Testament 14(1).

Yee, G.A., 2001, "She is not my wife and I am not her husband": A materialistic analysis of Hosea 1-2, Koninklijke Brill NV, Leiden. 